Original Article

\title{
Medium and large-sized mammals of a private protected wetland in the Cerrado-Amazon biological corridor, Brazil
}

\author{
Mamíferos de médio e grande porte em uma área alagável protegida no corredor \\ biológico Cerrado-Amazônia, Brasil
}

\author{
D. S. Silva ${ }^{a, b *}$ (D), M. V. Ribeiro ${ }^{b, c}$ (i) and F. H. Soares ${ }^{b}$ (D) \\ aUniversidade Federal de Goiás - UFG, Instituto de Ciências Biológicas, Programa de Pós-graduação em Biodiversidade Animal, Goiânia, GO, Brasil \\ 'Associação Guardiões do Cerrado - AGC, Serranópolis, GO, Brasil \\ 'Universidade Estadual de Santa Cruz - UESC, Programa de Pós-Graduação em Ecologia e Conservação da Biodiversidade, Ilhéus, BA, Brasil
}

\begin{abstract}
Brazil is the world's richest country in biodiversity, including mammal species. In the Brazilian Cerrado biome, mammalian diversity is vast, with about 251 species, 32 of them are endemic and 22 listed as threatened species. In this work, we investigated species diversity of medium- and large-sized mammals in the private protected area RPPN Pontal do Jaburu (RPPN-PJ) and its surroundings, which is a flooded area located in an important biological corridor in the Cerrado-Amazon ecotone zone, a priority area for biodiversity conservation in Brazil. We used camera-trapping, active search (night and day), and track survey during dry season (Apr - Aug 2016). We recorded 29 mammal species, being the Carnivora order the most representative with 11 species. Regarding threat status, $35.7 \%$ of the recorded species were listed as threatened in Brazil and 32.1\% worldwide. We highlight the high relative frequency of threatened species records such as Tapirus terrestris, Panthera onca, Blastocerus dichotomus, Pteronura brasiliensis, Priodontes maximus, and other, as well as the presence of the newly described aquatic mammal species Inia araguaiaensis. We stress the importance of RPPN-PJ and its surroundings for mammal conservation, which include complex habitats (wetlands) located in an important ecotone zone.
\end{abstract}

Keywords: Brazilian savannah, threatened species, camera-trap, ecotone zone, RPPN.

\begin{abstract}
Resumo
O Brasil é o país mais rico em biodiversidade no mundo, incluindo espécies de mamíferos. No bioma Cerrado, a diversidade de mamíferos é enorme, com cerca de 251 espécies, sendo 32 delas endêmicas e 22 listadas como ameaçadas de extinção. Neste estudo, investigamos a diversidade de espécies de mamíferos de médio e grande porte da RPPN Pontal do Jaburu (RPPN-PJ) e seu entorno, que é uma floresta de inundação localizada em um importante corredor biológico na zona de ecótono Cerrado-Amazonia, uma área prioritária para conservação da biodiversidade no Brasil. Os dados foram coletados por armadilhas fotográficas, busca ativa (noturna e diurna) e identificação de pegadas durante a estação seca (abril - agosto de 2016). Registramos um grande número de espécies de mamíferos $(n=29)$, sendo a ordem carnívora a mais representativa com 11 espécies. Com relação ao status de ameaça, $34,5 \%$ das espécies registradas foram listadas como ameaçadas na lista vermelha do Brasil e $20,7 \%$ na lista vermelha da IUCN. Destacamos a alta frequência relativa de registros de espécies ameaçadas como Tapirus terrestris, Panthera onca, Blastocerus dichotomus, Pteronura brasiliensis, Priodontes maximus, bem como a presença da recém descrita espécie de mamífero aquático Inia araguaiaensis. Nós discutimos a importância da RPPN-PJ e seus arredores para a conservação de espécies de mamíferos, onde inclui habitats complexos (áreas de inundação) localizados em uma importante zona de ecótono.. Os resultados reforçam a relevância desta área para a conservação de mamíferos.
\end{abstract}

Palavras-chave: Savana brasileira, espécies ameaçadas, armadilhas fotográficas, zonas de ecótono, RPPN.

\section{Introduction}

Brazil is considered the country with the richest biodiversity in the world, being responsible for approximately $14 \%$ of the world's biodiversity (Mittermeier, 1997; Lewinsohn and Prado, 2002) with more than 750 mammal species (Abreu Junior et al., 2020; Quintela et al.,
2020). However, due to several threats (e.g., fragmentation, habitat loss, among others), at least 110 species have been categorized into some threat status of extinction risk, according to the Brazilian red list of threatened species (ICMBIO, 2018). 
The Cerrado is the most biodiversity-rich savannah in the world, and the second-largest Brazilian biome (Klink and Machado, 2005). It is considered one of the world's hotspots for biodiversity conservations due to its high number of endemic species and increasing anthropogenic pressure (Myers et al., 2000). Even though more than half of the Cerrado has been converted to pastures or other anthropogenic land uses (Klink and Machado, 2005), it still has a high diversity of mammal species with more than 251 recorded, of which 32 are considered endemic (Paglia et al., 2012; ICMBIO, 2018). However, according to the Brazilian Red List of Threatened Species (ICMBIO, 2018) and the Red List of Threatened Species by the International Union for Conservation of Nature (IUCN, 2020), at least 41 mammal species are listed as threatened in the Cerrado (Gutiérrez and Marinho-Filho, 2017; ICMBIO, 2018).

In this context, an effective strategy for protecting biodiversity, ecosystem services, historical and cultural values are the Protected Areas (PAs). However, the Cerrado has less than $10 \%$ of its entire extension formally protected by PAs, which are not fully effective in protecting threatened species and ecosystems (Fonseca et al., 2010; Klink and Machado, 2005). Therefore, only 3\% of these PAs are categorized as strict protection, while more than $5 \%$ fall into sustainable use categories, including private protected areas (PPAs), known in Brazil as "Reserva Particular do Patrimônio Natural (RPPN)", covering about $0,07 \%$ of the Cerrado domain (Françoso et al., 2015).

The Brazilian system of PAs (Federal Law 9985/2000) is responsible for regulating and managing public or private PAs, such as the RPPNs, which has been increasingly useful in conserving biodiversity, allowing private landowners, NGOs, or companies to create them (Wiedmann, 2001). Furthermore, RPPNs play a fundamental role in biological conservation since they allow the implementation of ecological corridors, ensuring wildlife movement, providing foraging areas, dispersion opportunities, and gene flow between populations (Lima and Franco, 2014). Thus, creating RPPNs has become a promising strategy to increment thee network of PAs because there are many important areas for biodiversity conservation within private areas, and expropriation is a long-term and costly process (Bensusan, 2006).

In the Cerrado are the headwaters of the three major hydrographic basins of South America. The Araguaia River is the largest in Brazil's wet-dry tropics, being $2110 \mathrm{~km}$ long, and it is the main Cerrado drainage system (Latrubesse et al., 2009). The lower Araguaia river floodplains consist of flooded areas during the rainy season that form a mosaic of essential habitats for the maintenance of biodiversity (Agostinho and Zalewski, 1996), and its hydrological cycle has a fundamental role in the seasonal distribution of some mammalian species (Ramalho and Magnusson, 2009). Thus, environments with floodable areas are considered priority areas for the conservation of biodiversity (Diniz-Filho et al., 2009; Brasil, 2007). Thus, we aimed to evaluate the species richness and composition of medium and large-sized mammals in the RPPN Pontal do Jaburu and surroundings, which is an important seasonally flooded area on the Araguaia riverbank in the Cerrado-Amazon biological corridor. The present work represents a valuable example of the importance of RPPNs for biodiversity conservation in the Cerrado.

\section{Material and Methods}

\subsection{Study area}

The survey was carried out in the private protected area RPPN Pontal do Jaburu (RPPN-PJ) (13²5’11.97“ S $50^{\circ} 37^{\prime} 11.01^{\prime \prime} \mathrm{W}$ ) and its surroundings, in the area owned by Grupo Villas Boas. The RPPN was created through Portaria No. 38 of June 26, 2000, covering about 2.900 hectares. The area is located at a confluence between the Crixás and Araguaia rivers, in the municipality of Nova Crixás, Goiás state, within the borders of the "Area de Proteção Ambiental Meandros do Rio Araguaia", a protected area managed by the Brazilian environmental agency Instituto Chico Mendes de Conservação da Biodiversidade (ICMBio). The RPPN-PJ is a floodplain located in the Cerrado biome, which is characterized by a mosaic of phytophysiognomies (Ribeiro and Walter, 1998) and has two climatic seasons: a rainy season ranging from October to March and a dry season from April to September (Macena et al., 2008). The landscape of the RPPN-PJand its surroundings is characterized by wetlands predominantly covered by natural vegetation varying from forest formations to savannah as well as cattle ranches and urban areas (local communities and summer houses) in its surroundings.

\subsection{Data collection}

Data collection on medium-sized ( $>1 \mathrm{~kg}$ ) and large-sized (>15 kg) mammals were carried out during the dry season (April - August 2016) using three different methods (camera-trap, active search, and track survey). We have used eight camera-traps ( ${ }^{\circledR}$ Bushnell) during $24 \mathrm{~h} /$ day (Srbek-Araujo e Chiarello, 2007) at different stations (1 camera per station) within the RPPN-PJ(2904 ha) and in its surroundings ( $968 \mathrm{ha}$ ) (Figure 1). The camera-traps were checked every 30 days and were configured to make videos of 30 seconds with each shot (1 second of interval between shots). The stations were chosen in order to represent different landscapes (savannah and riparian forest) according to the availability of dry areas, since until June some parts of the reserve were still flooded. Camera-traps were placed with a minimum distance of $3.6 \mathrm{~km}$ from each other. During active search and track survey, we aimed to visualize mammals and to search for tracks (during night and day periods) using a car in dirt roads, boat on the ponds and rivers, and walking on trails use by mammals across the forest.

\subsection{Data analysis}

The species were identified following Patton et al. (2015) for Rodentia, Rylands et al. (2012) for Primates and Wilson and Reeder (2005), and Paglia et al. (2012) for other taxa; tracks were identified using specialized literature (Becker and Dalponte, 1991; Emmons and Feer 1997). Species nomenclature followed the most recent 


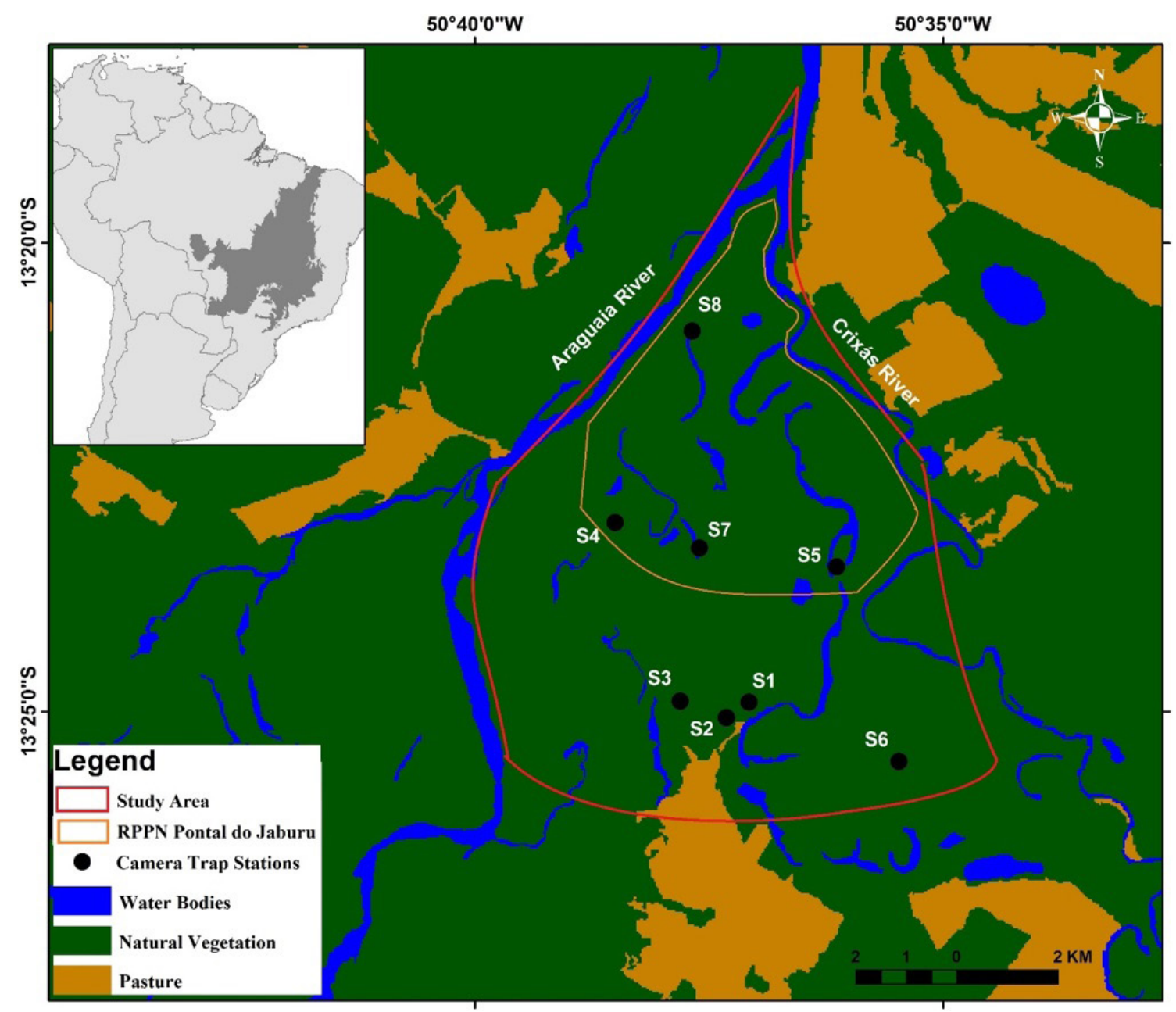

Figure 1. Study area located along Araguaia river and Crixás Sul river in the municipality of Nova Crixás, State of Goiás, Brazilian Cerrado biome. Black dots represent camera-trap stations.

publication of the Brazilian Society of Mammalogy (Abreu Junior et al., 2020).

Statistical treatments were performed based on data only from camera-trap records. The relative frequency of each species was calculated through the number of records divided by total number of camera-trap days X 100 (Cullen Jr. et al. 2004). The species accumulation curve summarizes in a graph composed by orthogonal axes (accumulated species richness and sampling efforts). In general, the curve shows initial upward curve of accelerated growth, reducing the slope according increases sampling efforts until reach a plateau (Martins and Santos, 1999).

The estimated species richness was calculated using the Jackknife 1 index, which is based on the number of species found in a sample. We also used the Bootstrap richness estimator based on the proportion of records for each species. The curves (accumulation and estimators) were obtained through the number of species observed and estimated based on the sampling effort (sampling days). However, sample collection order was randomized 1,000 times, and an average curve (based on the average richness for each sample number) was constructed for the curves (Magurran, 2013). For the calculations, we used the vegan package (Oksanen et al., 2013) available in R 3.6.1 (R Development Core Team, 2019).

\section{Results and Discussion}

During the survey period, we accumulated 928 trap-days and $189 \mathrm{~h}$ of active search and track survey efforts, resulting in the record of 29 medium- and large-sized mammals (Table 1), which corresponds to $68 \%$ of the species from this group expected to occur in the Cerrado (Marinho-Filho et al., 2002). Camera-traps recorded the highest number of species ( $n=23$ ), representing $82 \%$ of all recorded species, even with a low number of stations $(\mathrm{n}=8)$ and short-term survey. The camera trap records can be accessed on supplementary materials (Figure supplementary 1 and Figure supplementary 2). On the other hand, 14 species ( $48 \%$ ) were recorded through sighting and 13 species ( 45\%) through track survey. 
Table 1. Medium- and large-sized mammal species recorded in RPPN Pontal do Jaburu and its surroundings, Goiás, Brazil, showing the sampling methods and their threat status in Brazil (ICMBIO, 2018) and globally (IUCN, 2020).

\begin{tabular}{|c|c|c|c|c|}
\hline \multirow{2}{*}{ Taxon } & \multirow{2}{*}{ Common Name } & \multirow{2}{*}{ Method } & \multicolumn{2}{|c|}{ Threat Level } \\
\hline & & & Brazilian & IUCN \\
\hline \multicolumn{5}{|l|}{ ARTIODACTYLA } \\
\hline \multicolumn{5}{|l|}{ Tayassuidae } \\
\hline Dicotyles tajacu (Linnaeus, 1758) & Collared peccary & $\mathrm{C}, \mathrm{S}, \mathrm{T}$ & & LC \\
\hline Tayassu pecari (Link, 1795) & White-lipped peccary & C, T & VU & VU \\
\hline \multicolumn{5}{|l|}{ Cervidae } \\
\hline Mazama gouazoubira G. Fischer [von Waldheim], 1814 & Gray brocket & $\mathrm{C}, \mathrm{S}, \mathrm{T}$ & & LC \\
\hline Mazama americana (Erxleben, 1777) & Red brocket & $\mathrm{C}, \mathrm{T}$ & & $\mathrm{DD}$ \\
\hline Blastocerus dichotomus (Illiger, 1815) & Marsh deer & $\mathrm{C}, \mathrm{S}, \mathrm{T}$ & & VU \\
\hline \multicolumn{5}{|l|}{ CARNIVORA } \\
\hline \multicolumn{5}{|l|}{ Canidae } \\
\hline Cerdocyon thous (Linnaeus, 1766) & Crab-eating fox & $\mathrm{C}, \mathrm{S}, \mathrm{T}$ & & LC \\
\hline Chrysocyon brachyurus (Illiger, 1815) & Maned wolf & $\mathrm{C}$ & VU & NT \\
\hline \multicolumn{5}{|l|}{ Felidae } \\
\hline Panthera onca (Linnaeus, 1758) & Jaguar & C, T & VU & NT \\
\hline Puma concolor (Linnaeus, 1771) & Puma & $C, T$ & VU & LC \\
\hline Herpailurus yagouaroundi (É. Geffroy SantHilare, 1803) & Jaguarundi & $\mathrm{C}$ & VU & LC \\
\hline Leopardus pardalis (Linnaeus, 1758) & Ocelot & C, $\mathrm{T}$ & & LC \\
\hline \multicolumn{5}{|l|}{ Mustelidae } \\
\hline Pteronura brasiliensis (Gmelin, 1788) & Giant otter & C, S & VU & EN \\
\hline Lontra longicaudis (Olfers, 1818) & Neotropical otter & S & & NT \\
\hline Eira barbara (Linnaeus, 1758) & Tayra & $\mathrm{C}$ & & LC \\
\hline Procyonidae & & & - & \\
\hline Nasua (Linnaeus, 1766) & South American coati & $\mathrm{C}$ & & LC \\
\hline Procyon cancrivorus (Linnaeus, 1758) & Crab-eating raccoon & $\mathrm{C}$ & & LC \\
\hline \multicolumn{5}{|l|}{ PERISSODACTYLA } \\
\hline \multicolumn{5}{|l|}{ Tapiridae } \\
\hline Tapirus terrestris Linnaeus, 1758 & Tapir & C, S, T & VU & VU \\
\hline \multicolumn{5}{|l|}{ RODENTIA } \\
\hline \multicolumn{5}{|l|}{ Erethizontidae } \\
\hline Coendou prehensilis (Linnaeus, 1758) & Brazilian porcupine & $\mathrm{S}$ & & LC \\
\hline \multicolumn{5}{|l|}{ Cuniculidae } \\
\hline Cuniculus paca (Linnaeus, 1766) & Lowland paca & $\mathrm{C}$ & & LC \\
\hline \multicolumn{5}{|l|}{ Dasyproctidae } \\
\hline Dasyprocta leporina (Linnaeus, 1758) & Red-rumped agouti & S & & $\mathrm{LC}$ \\
\hline \multicolumn{5}{|l|}{ Caviidae } \\
\hline Hydrochoerus hydrochaeris (Linnaeus, 1766) & Capibara & $\mathrm{C}, \mathrm{S}, \mathrm{T}$ & & LC \\
\hline \multicolumn{5}{|l|}{ CINGULATA } \\
\hline \multicolumn{5}{|l|}{ Dasypodidae } \\
\hline Dasypus novemcinctus Linnaeus, 1758 & Nine-banded armadillo & $\mathrm{C}$ & & LC \\
\hline Priodontes maximus (Kerr, 1792) & Giant armadillo & C, T & VU & VU \\
\hline
\end{tabular}

LC = Least Concern; VU = Vulnerable; NT = Near Threatened; CR = Critically Endangered; EN=Endangered; DD=Data Deficient. Record Methods: $\mathrm{C}=$ camera-trap; $\mathrm{S}=$ Sighting; $\mathrm{T}=$ Track Survey. 
Table 1. Continued...

\begin{tabular}{|c|c|c|c|c|}
\hline \multirow{2}{*}{ Taxon } & \multirow{2}{*}{ Common Name } & \multirow{2}{*}{ Method } & \multicolumn{2}{|c|}{ Threat Level } \\
\hline & & & Brazilian & IUCN \\
\hline \multicolumn{5}{|l|}{ PILOSA } \\
\hline \multicolumn{5}{|l|}{ Myrmecophagidae } \\
\hline Myrmecophaga tridactyla (Linnaeus, 1758) & Giant anteater & $\mathrm{C}, \mathrm{S}, \mathrm{T}$ & VU & VU \\
\hline Tamandua tetradactyla (Linnaeus, 1758) & Southern tamandua & S & & LC \\
\hline \multicolumn{5}{|l|}{ PRIMATES } \\
\hline \multicolumn{5}{|l|}{ Atelidae } \\
\hline Alouatta caraya (Humboldt, 1812) & Black howler & $\mathrm{C}$ & CR & LC \\
\hline \multicolumn{5}{|l|}{ Cebidae } \\
\hline Sapajus libidinosus (Spix, 1823) & Bearded capuchin & C, S & & LC \\
\hline \multicolumn{5}{|l|}{ CETARTIODACTYLA } \\
\hline \multicolumn{5}{|l|}{ Iniidae } \\
\hline Inia araguaiaensis (Hrbek, Farias, Dutra e da Silva 2014) & Araguaian river dolphin & S & & \\
\hline \multicolumn{5}{|l|}{ DIDELPHIMORPHYA } \\
\hline \multicolumn{5}{|l|}{ Didelphidae } \\
\hline Didelphis albiventris Lund, 1840 & White-eared Opossum & C & & LC \\
\hline
\end{tabular}

LC = Least Concern; VU = Vulnerable; NT = Near Threatened; CR = Critically Endangered; EN=Endangered; DD=Data Deficient. Record Methods: $\mathrm{C}=$ camera-trap; $\mathrm{S}=$ Sighting; $\mathrm{T}=$ Track Survey.

The species richness we found by camera-trap records (Sob $=23$ ) was close to the richness estimated by Bootstrap (Sboot $=25 \pm 4.63$ ) and Jackniffe1 estimators $($ Sjack $=27 \pm 4.70)$. The accumulation curve did not show a tendency to stabilization, demonstrating that new species may still emerge with increased sampling effort (see Figure 2). It is noteworthy that we considered only the camera-trap records in this analysis, but if we considered the complementary methods (active search and track survey), the species richness would be higher than the estimated.

Our study showed high species diversity when compared to other studies carried out across the Brazilian Cerrado (see Table 2), These studies have used different methods and sampling efforts, as well as they were carried out in different landscapes in other parts of the Cerrado biome domain, since there are no studies on medium and largesized mammals along the Cerrado-Amazon ecotone zone, making difficult to perform more comprehensive comparisons.

Regarding the threat status of recorded species, ten species were listed as threatened in the Brazilian Red List of Threatened Species (ICMBIO, 2018), being nine species listed as Vulnerable (VU) and one as Critically Endangered (CR), representing $34.5 \%$ of the total recorded species. On the other hand, six species were listed as threatened in the IUCN Red List of Threatened Species (IUCN, 2020), five species were listed as Vulnerable (VU) and another one as Endangered (EN), representing $20.7 \%$ of recorded species.

The Carnivora was the most representative order with 11 species (38\%), highlighting jaguar (Panthera onca) and puma (Puma concolor) as apex predators and threatened species in Brazil (ICMBIO, 2018). Apex predators are an indicative of environmental health and perform an important role in regulating prey populations (Schmitz, 2010; Terborgh, 2012; Allen et al., 2014). Apex predators demand large home ranges with abundant prey and may become vulnerable to habitat loss and fragmentation (Ripple et al., 2014). In this context, there is concern about jaguar conservation in the Cerrado since this biome has already lost $46 \%$ of its native vegetation, which has been converted mainly to pasture and croplands (Strassburg et al., 2017). PAs implementation is a valuable strategy for long-term conservation of large carnivores (Ripple et al., 2014). However, less than $8 \%$ of the Cerrado territory is covered by PAs (Françoso et al., 2015). Thus, PAs are invaluable to jaguar conservation in the Cerrado, such as RPPN-PJ, which is located within high priority areas for jaguar conservation in this biome (Portugal et al., 2019).

The relative frequency of jaguar and puma records (see Figure 3) estimated through camera-trap during this survey were $7.6 \%$ and $2.8 \%$, respectively. While jaguar relative frequency was higher than other similar surveys carried out in the Cerrado, puma relative frequency was similar (Trolle et al., 2007, Paolino et al., 2016; Leite et al., 2016; Cabral et al., 2017; Laurindo et al., 2019; Arimoro et al., 2020). Furthermore, in the aforementioned studies, the relative frequency of pumas was higher when compared to the one estimated for jaguars when both species were recorded. However, herein, we have found that jaguar relative frequency is 2.7 times higher than puma relative frequency, which is similar to studies carried out in the Pantanal (Porfirio et al., 2014; Coe, 2018), an area with high density and abundance for jaguar populations (Soisalo and Cavalcanti, 2006) in Brazil. Whereas prey 
Table 2. Number of medium and large-sized mammal species recorded by studies carried out along the Brazilian Cerrado.

\begin{tabular}{lccl}
\hline \multicolumn{1}{c}{ Studies } & Species $(\mathbf{n})$ & Area (há) & \multicolumn{1}{c}{ Location of Study Area } \\
\hline Our study & 29 & 2,900 & Cerrado-Amazon ecotone zone. \\
Arimoro et al., 2020 & 29 & 114,985 & Military area in the central of Cerrado. \\
Leite et al., 2016 & 27 & $3,353.18$ & Brasília Nacional Forest in the Central of Cerrado. \\
Paolino et al., 2016 & 26 & 9,013 & Jataí Ecological Station in the southern of Cerrado \\
Oliveira et al., 2019 & 23 & - & Nine different patches of natural forest remnants. \\
Laurindo et al., 2019 & 19 & - & $\begin{array}{l}\text { Four remnants of natural vegetation and adjacent agricultural in the } \\
\text { Southeastern of Cerrado. }\end{array}$ \\
Trolle et al., 2007 & 18 & 1,760 & $\begin{array}{l}\text { In a farm in the southeastern of Cerrado with pasture, crop lands and } \\
\text { native vegetation. }\end{array}$ \\
Cabral et al., 2017 & 17 & 8,730 & RPPN Serra do Tombador located in the central of Brazilian Cerrado . \\
\hline
\end{tabular}

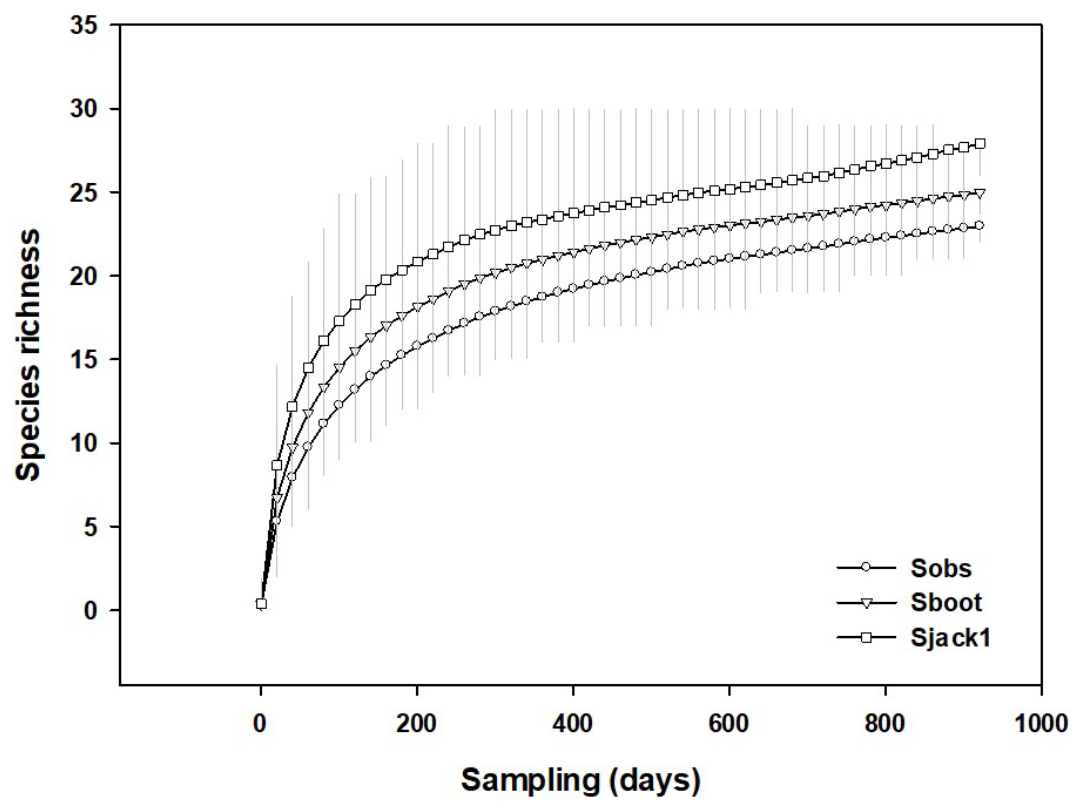

Figure 2. Species accumulation curve of medium- and large-sized mammals recorded by camera-traps in the RPPN Pontal do Jaburu and its surroundings, Goiás, Brazil. Whiskers represent the 95\% confidence interval. Sob = Observed richness; Sboot = Richness estimated by the Bootstrap estimator; Sjack1 = Richness estimated by the Jackniffe 1 estimator.

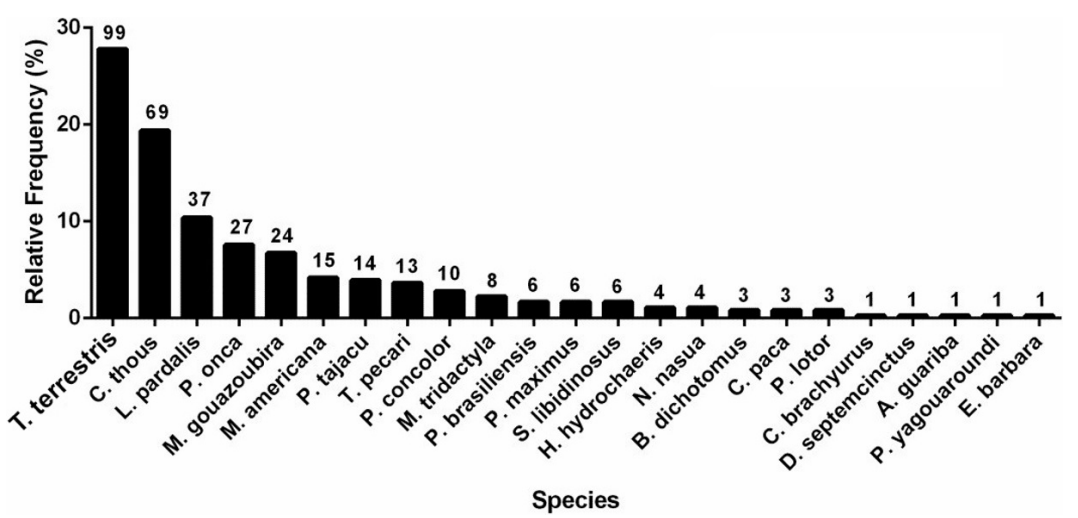

Figure 3. Relative frequency (\%) and number of records (over the bars) for each medium- and large-sized mammal species recorded by camera-traps in the RPPN Pontal do Jaburu and its surroundings, Goiás, Brazil. 
populations base is essential to support and influence jaguar population size (Azevedo and Murray, 2007), in this survey, we recorded several large prey consumed by jaguars, such as lowland tapir (Tapirus terrestris), giant anteater (Myrmecophaga tridactyla), peccaries (Tayassu pecari and Dicotyles tajacu), capybara (Hydrochoerus hydrochaeris), marsh deer (Blastocerus dichotomus)(Azevedo and Murray, 2007) and giant otter (Pteronura brasiliensis) (Ramalheira et al., 2015). Moreover, the region is also home to large populations of black caiman (Melanosuchus niger) and spectacled caiman (Caiman crocodilus), potential large prey for the jaguar (Marioni et al., 2013). We also highlight the record of at least two melanic individuals of jaguar (male and female) in the study area. Although the frequency of melanism in jaguars is around $10 \%$, it can vary throughout the jaguar distribution (Mooring et al., 2020). However, the frequency of melanism in jaguars in the Meandros do Araguaia region, and the Cerrado biome remains unknown. Furthermore, studies that evaluated jaguar density and abundance in the Cerrado are scarce; thus, we stress the need for more studies on the jaguar population in the Meandros do Araguaia region.

The lowland tapir was the most frequent species (see Figure 2) recorded by camera-traps (relative frequency =27\%), which is higher than relative frequencies found by other camera-trap surveys in the Cerrado: 16.9\% (Oliveira et al., 2019) and $11.0 \%$ (Arimoro et al., 2020). This species inhabits a wide variety of environments, such as riparian forests, savannah, tropical forests, and seasonally flooded areas; however, it shows a preference for forested environments associated with permanent water sources (Medici, 2010). Forest formations that cover most of our study area, in addition to the large flooded areas (seasonally or permanently), make the RPPN-PJ a highly suitable environment for the lowland tapir. The species is listed as Vulnerable (VU) in both IUCN and Brazilian red lists (ICMBIO, 2018; Medici et al., 2018; Varela et al., 2019), but its threat status varies across Brazilian biomes (Medici et al., 2012). Although studies on lowland tapir populations are scarce in the Cerrado, it is estimated that their occupation area in this biome has been reduced by around $67 \%$, remaining about 130,000 individuals, which is equivalent to a density of 0.13 lowland tapir $/ \mathrm{km}^{2}$ (Medici et al., 2012; Medici and Desbiez, 2012), being lower than lowland tapir density in the other Brazilian biomes where the species is present: Amazon $0.21-0.71$ individuals / $\mathrm{km}^{2}$; Atlantic Forest; and Pantanal 0.21 - 0.71 individuals / $\mathrm{km}^{2}$ (Cordeiro, 2004; Trolle et al., 2008; Desbiez, 2009). However, there is no data about lowland tapir populations in the Cerrado flooded areas, thus further studies on this species in the Meandros do Araguaia region are needed since there may be a crucial corridor for its conservation.

The vulnerable species marsh deer (Blastocerus dichotomus) and giant armadillo (Priodontes maximus) were important records during our survey because the population of these species is declining due to several threats, such as fragmentation and habitat loss, land-use change, hunting, dams, and diseases (Keuroghlian et al., 2013; Anacleto et al., 2014; Duarte et al., 2016). The marsh deer is the largest South American deer reaching $125 \mathrm{~kg}$ (Pinder and Grosse, 1991), which has had a wide geographical distribution throughout South America, but currently, it has a restricted distribution with reduced and fragmented populations (Tiepolo and Tomas, 2006). This deer is a marsh-dependent species where the hydrologic balance is critical; however, deep inundations caused by hydroelectric dams and water drainage to agriculture have destroyed their habitats (Andriolo et al., 2013). In this context, it is valuable to protect flooded areas such as RPPN-PJ to conserve marsh deer populations. Regarding the giant armadillo (the world's largest living species of armadillo), it plays a significant ecological role, being known as ecosystem engineers due to its excavations creating new habitats and several species are associated with its burrows (Desbiez and Kluyber, 2013; Aya-Cuero et al., 2017). Such species has large home-range areas ( 2500 ha) living in low densities with low home-range overlap between individuals (Desbiez et al., 2020); thus, protecting large areas is essential for giant armadillo conservation.

Both species from the Tayassuidae family extant in Brasil, collared peccary (Dicotyles tajacu), and white-lipped peccary (Tayassu pecari), were recorded in our survey with very similar relative frequency ( $3.9 \%$ and $3.7 \%$ respectively). However, collared peccary (solitary individuals or herds reaching 15 individuals) was recorded only at two camera-trap stations (S1 and S2), which are near to reserve buildings and the border with a cattle ranch, while white-lipped peccary (always in herds reaching $\sim 80$ individuals) has been recorded at four camera-trap stations (S4, S5, S6, and S8) in isolated areas under low disturbance. White-lipped peccaries are described to have a seasonally varied home range much larger than the stable collared peccaries home range (Peres, 1996; Fragoso, 1998; Keuroghlian et al., 2004; Hofman et al., 2016), which can explain the slightly higher number of white-lipped peccaries records. Although studies have reported niche overlap between these species, collared peccaries forage at a different time period to avoid competition with white-lipped peccaries (Desbiez et al., 2009; Galetti et al., 2015). Our results do not show the two species using the same area during the period of the survey, suggesting that collared peccaries can also avoid areas occupied by white-lipped peccaries. Understanding coexistence and habitat use of these species is of paramount importance to create and manage PAs to protect them. Regarding extinction risk, the collared peccary is not listed as threatened species and occurs in most of its original range (Gongora et al., 2011), while the sympatric white-lipped peccary has disappeared from several parts of its original range and it is a threatened species (Keuroghlian et al., 2013). Despite threats such as hunting, disease and habitat loss and fragmentation affect by similar ways the two species, the white-lipped peccary has faced more retaliation due to crop damage (Jácomo, 2004; Lima et al., 2019). Although the Meandros do Araguaia region is mainly covered by natural vegetation and pastures, the agriculture frontier has advanced there. Therefore, is very important to create strategies for white-lipped peccary conservation in this region to ensure its persistence in the Cerrado, since it plays very important ecological roles and are also recognized as ecosystem engineers (Keuroghlian and Eaton, 2009; Beck et al., 2010). 
Two species from Canidae family were recorded in this survey, the medium-sized canid crab-eating fox (Cerdocyon thous) and the largest South American canid maned wolf (Chrysocyon brachyurus). The crab-eating fox has been listed as non-threatened species with stable populations across its range (Lucherini, 2015), presenting the second highest relative frequency (19.4\%) from camera-trap records at three stations (S1, S2 and S7) settled in open areas under less flooded influence. As for the maned wolf, it is listed as vulnerable species in the Brazilian red list and it has been recorded by camera-trap in this survey only once at S2. Despite the two species are described to be omnivorous, studies have reported low food niches overlap between them, being crab-eating fox more generalist than the maned wolf (Aragona and Setz, 2001; Bueno and Motta-Junior, 2004; Gatti et al., 2006). We highlight the single maned wolf record at S2 corroborating its preference for inhabiting open areas such as grasslands and savannah (Coelho et al., 2018), although it can also inhabit seasonally flooded wetlands (Beccaceci, 1992). We have not recorded the bush dog (Speothos venaticus) during our survey, being that the study area is located inside of the geographical distribution of this Canidae species (DeMatteo et al., 2011) and near to other areas where this species has been recorded (DeMatteo and Loiselle, 2008; Guimarães et al., 2015).

We have recorded mammal species associated to aquatic environments, both with semi-aquatic and strictly aquatic habits. Among these species, the endangered giant otter (Pteronura brasiliensis) has been recorded in our survey by both camera-trap and sightings. Unlike the neotropical otter (Lontra longicaudis), also recorded in our survey, which is not a threatened species and has wide distribution from Mexico to northern Argentina (Rheingantz and Trinca, 2015), the giant otter is restricted to South American central-northern region and are facing populations declining due hunting, human conflicts, shipping lanes, pollution, trap by fishing nets, habitat degradation and other impacts (Groenendijk et al., 2015; Noonan et al., 2017). Regarding aquatic mammal species, we have recorded the Araguaian river dolphin (Inia araguaiaensis), a recently described species (2014) that occurs in the Araguaia-Tocantins river basin, in central of Brazil (Hrbek et al., 2014). Although some studies have been performed on its natural history, ecology, communication, behavior, distribution, population size and human pressure (Siciliano et al., 2016; Moreira-Junior, 2017; Pereira, 2017; Pivari et al., 2017; Melo-Santos et al., 2019, 2020), there is poor scientific information about this species. In the Araguaia River, these animals have been described to be found in higher density in habitats with high sediment input, where tributaries rivers fall into Araguaia River (Araújo and Silva, 2014). The RPPN-PJ is located at the confluence of the Araguaia and Crixás rivers, where we have found Araguaian river dolphin everywhere along the largest water body ( $12 \mathrm{~km}$ length) inside the study area, which is perennially connected to Crixás river. In the other hand, we have not found Araguaian river dolphin in ponds seasonally connected by flood. However, more studies must be performed in this and other areas during dry and wet season in order to better understand habitat use by this species in flooded areas along the Araguaia river, since it have been threatened by eminent hydroelectric dams' construction along Araguaia-Tocantins basin (Pivari et al., 2017).

We have not recorded any alien species (exotic or domestic) during this survey in the study area, which is a positive data because its presence represents significant threats on biodiversity since it may affect environmental conditions and community composition and structure (Scholes and Biggs, 2005).

The high diversity of mammal species we have recorded is influenced by the location of the RPPN-PJ in an ecotone between Cerrado and Amazon, as well as been a floodplain, with complex habitats able to support high biodiversity (Rocha and Comunello, 2009), thus, being considered a priority for conservation (Brasil, 1999; Scaramuzza et al., 2008; WWF, 2015). These environments contribute to the spatio-temporal dynamics of riverside ecosystems, allowing the river dynamics to significantly influence the maintenance of local biodiversity (Ward and Stanford, 1995; Rocha and Comunello, 2009). Our results indicate the importance of RPPN-PJ and its surrounding for mammal conservation since it requires strategies such as PAsto prevent habitat loss and fragmentation (Thornton et al., 2011), and the study area is home for great diversity of medium- and large-sized mammal species.

The RPPN-PJ do not have a management plan, and our results can be used to show the importance of this area for the biodiversity conservation in the Cerrado since it is home for several threatened mammal species. As deforestation increases in the Cerrado, PPAs such as the RPPN-PJ are essential to ensure biodiversity conservation.

\section{Acknowledgements}

The authors are grateful to the Villas-Boas Group for logistic and financial support for this survey. We also thank AGC - Associação Guardiões do Cerrado, a non-profit NGO, for the financial support and fieldwork coordination.

\section{References}

ABREU JUNIOR, E.F., CASALI, D.M., GARBINO, G.S.T., LORETTO, D., LOSS, A.C., MARMONTEL, M., NASCIMENTO, M.C., OLIVEIRA, M.L., PAVAN, S.E. and TIRELLI, F.P., 2020 [viewed 22 January 2021]. Lista de mamíferos do Brasil. Comitê de Taxonomia da Sociedade Brasileira de Mastozoologia (CTSBMz). Available from: https://www.sbmz. org/mamiferos-do-brasil

AGOSTINHO, Â.A. and ZALEWSKI, M., 1996. A planície alagável do alto rio Paraná: importância e preservação. Maringá: EDUEM, 100 p.

ALLEN, M.L., ELBROCH, L.M., CASADY, D.S. and WITTMER, H.U., 2014. Seasonal variation in the feeding ecology of pumas (Puma concolor) in northern California. Canadian Journal of Zoology, vol. 92, no. 5, pp. 397-403. https://doi.org/10.1139/cjz-2013-0284.

ANACLETO, T.C.S., MIRANDA, F., MEDRI, I., CUELLAR, E., ABBA, A.M. and SUPERINA, M., 2014 [viewed 22 January 2021]. Priodontes maximus [online]. The IUCN Red List of Threatened Species. Available from: https://www.iucnredlist.org/ species/18144/47442343 
ANDRIOLO, A., PIOVEZAN, U., COSTA, M.J., TORRES, H.A., VOGLIOTTI, A., ZERBINI, A.N. and DUARTE, J., 2013. Severe population decline of marsh deer, Blastocerus dichotomus (Cetartiodactyla: Cervidae), a threatened species, caused by flooding related to a hydroelectric power plant. Zoologia, vol. 30, no. 6, pp. 630638. http://dx.doi.org/10.1590/S1984-46702013005000015.

ARAGONA, M. and SETZ, E.Z.F., 2001. Diet of the maned wolf, Chrysocyon brachyurus (Mammalia: Canidae), during wet and dry seasons at Ibitipoca State Park, Brazil. Journal of Zoology, vol. 254, no. 1, pp. 131-136. http://dx.doi.org/10.1017/ S0952836901000620.

ARAÚJO, C.C. and SILVA, V.M.F., 2014. Spatial distribution of river dolphins, Inia geoffrensis (Iniidae), in the Araguaia River (central Brazil). Mammalia, vol. 78, no. 4, pp. 481-486. http://dx.doi. org/10.1515/mammalia-2013-0112.

ARIMORO, O.A.S., LACERDA, A.C.R., TOMAS, W.M., ASTETE, S., ROIG, H.L. and MARINHO-FILHO, J., 2020. Artillery for conservation: the case of the mammals protected by the formosa military training area, Brazil. Tropical Conservation Science, vol. 10, no. 1.

AYA-CUERO, C., RODRIGUEZ-BOLAÑOS, A. and SUPERINA, M., 2017. Population density, activity patterns, and ecological importance of giant armadillos (Priodontes maximus) in Colombia. Journal of Mammalogy, vol. 98, no. 3, pp. 770-778. http://dx.doi. org/10.1093/jmammal/gyx006.

AZEVEDO, F.C.C. and MURRAY, D.L., 2007. Spatial organization and food habits of jaguars (Panthera onca) in a floodplain forest. Biological Conservation, vol. 137, no. 3, pp. 391-402. http:// dx.doi.org/10.1016/j.biocon.2007.02.022.

BECCACECI, M.D., 1992. The maned wolf, Chrysocyon brachyurus, Argentina. In: B. Matern, ed. Internacionales Zuchtbuch für den Mänhenwolf, Chrysocyon brachyurus (Illiger, 1811). Frankfrut: Zoologischer Garten Frankfurt am Main, pp. 50-56.

BECK, H., THEBPANYA, P. and FILIAGGI, M., 2010. Do Neotropical peccary species (Tayassuidae) function as ecosystem engineers for anurans? Journal of Tropical Ecology, vol. 26, no. 4, pp. 407414. http://dx.doi.org/10.1017/S0266467410000106.

BECKER, M. and DALPONTE, J.C., 1991. Rastros de mamíferos silvestres brasileiros: um guia de campo. Brasília: Editora Universidade de Brasília.

BENSUSAN, N., 2006. Conservação da biodiversidade em áreas protegidas. Rio de Janeiro: FGV Editora.

BRASIL. MINISTÉRIO DO MEIO AMBIENTE - MMA, 1999. First national report for the Convention on Biological Diversity. Secretaria de Biodiversidade e Florestas, Brasília.

BRASIL. MINISTÉRIO DO MEIO AMBIENTE - MMA, 2007. Áreas Prioritárias para Conservação, Uso Sustentável e Repartição de Benefícios da Biodiversidade Brasileira: atualização - Portaria MMA n ${ }^{\circ}$, de 23 de janeiro de 2007. Secretaria de Biodiversidade e Florestas, Brasília. [Série Biodiversidade, 31].

BUENO, A.D.A. and MOTTA-JUNIOR, J.C., 2004. Food habits of two syntopic canids, the maned wolf (Chrysocyon brachyurus) and the crab-eating fox (Cerdocyon thous), in southeastern Brazil. Revista Chilena de Historia Natural, vol. 77, no. 1, pp. 5-14.

CABRAL, R., ZANIN, M., PORFÍRIO, G. and BRITO, D., 2017. Mediumsized to large mammals of Serra do Tombador, Cerrado of Brazil. Check List, vol. 13, no. 3, pp. 1-6. http://dx.doi. org/10.15560/13.3.2129.

COE, L.E., 2018. Diversity and composition of mammal and bird communities in northern Pantanal. Corvallis: Oregon State University. Thesis.

COELHO, L., ROMERO, D., QUEIROLO, D. and GUERRERO, J.C., 2018. Understanding factors affecting the distribution of the maned wolf(Chrysocyon brachyurus) in South America: spatial dynamics and environmental drivers. Mammalian Biology, vol. 92, no. 1, pp. 54-61. http://dx.doi.org/10.1016/j.mambio.2018.04.006.

CORDEIRO, J.L.P., 2004. Estrutura e heterogeneidade da paisagem de uma unidade de conservação no nordeste do Pantanal (RPPN SESC Pantanal), Mato Grosso, Brasil: efeitos sobre a distribuição e densidade de antas (Tapirus terrestris) e de cervos-do-pantanal (Blastocerus dichotomus). Porto Alegre: Universidade Federal do Rio Grande do Sul. PhD Thesis.

DEMATTEO, K., MICHALSKI, F. and LEITE-PITMAN, M.R.P., 2011 [viewed 06 November 2020]. Speothos venaticus [online]. The IUCN Red List of Threatened Species. Available from: https:// www.iucnredlist.org/species/20468/9203243

DEMATTEO, K.E. and LOISELLE, B.A., 2008. New data on the status and distribution of the bush $\operatorname{dog}$ (Speothos venaticus): evaluating its quality of protection and directing research efforts. Biological Conservation, vol. 141, no. 10, pp. 2494-2505. http://dx.doi. org/10.1016/j.biocon.2008.07.010.

DESBIEZ, A.L.J. and KLUYBER, D., 2013. The role of giant armadillos (Priodontes maximus) as physical ecosystem engineers. Biotropica, vol. 45, no. 5, pp. 537-540. http://dx.doi.org/10.1111/ btp.12052.

DESBIEZ, A.L.J., 2009. Lowland tapirs in the Nhecolânia Region of Brazilian Pantanal: population density, habitat use and threats. Tapir Conservation, vol. 18, no. 25, pp. 7-10.

DESBIEZ, A.L.J., KLUYBER, D., MASSOCATO, G.F., OLIVEIRA-SANTOS, L.G.R. and ATTIAS, N., 2020. Spatial ecology of the giant armadillo Priodontes maximus in Midwestern Brazil. Journal of Mammalogy, vol. 101, no. 1, pp. 151-163. http://dx.doi. org/10.1093/jmammal/gyz172.

DESBIEZ, A.L.J., SANTOS, S.A., KEUROGHLIAN, A. and BODMER, R.E., 2009. Niche partitioning among white-lipped peccaries (Tayassu pecari), collared peccaries (Pecari tajacu), and feral pigs (Sus scrofa). Journal of Mammalogy, vol. 90, no. 1, pp. 119-128. http://dx.doi.org/10.1644/08-MAMM-A-038.1.

DINIZ-FILHO, J.A.F., BINI, L.M., OLIVEIRA, G., BARRETO, B.D.S., SILVA, M.M.F.P.D., TERRIBILE, L.C. and MELO, A.S., 2009. Macroecologia, biogeografia e áreas prioritárias para conservação no cerrado. Oecologia Australis, vol. 13, no. 3, pp. 470-497.

DUARTE, J.M.B., VARELA, D., PIOVEZAN, U. and BECCACECI, M.D. and GARCIA, J.E., 2016 [viewed 06 November 2020]. Blastocerus dichotomus [online]. The IUCN Red List of Threatened Species. Available from: https://www.iucnredlist.org/ species/2828/22160916

EMMONS, L. and FEER, F., 1997. Neotropical rainforest mammals: a field guide. Chicago: The University of Chicago Press.

FONSECA, P.O.R.M., LAMAS, I. and KASECKER, T., 2010. O Papel das Unidades de Conservação. Scientific American, vol. 39, pp. 18-23.

FRAGOSO, J.M., 1998. Home range and movement patterns of White-lipped Peccary (Tayassu pecari) herds in the Northern Brazilian Amazon. Biotropica, vol. 30, no. 3, pp. 458-469. http:// dx.doi.org/10.1111/j.1744-7429.1998.tb00080.x.

FRANÇOSO, R.D., BRANDÃO, R., NOGUEIRA, C.C., SALMONA, Y.B., MACHADO, R.B. and COLLI, G.R., 2015. Habitat loss and the effectiveness of protected areas in the Cerrado Biodiversity Hotspot. Natureza \&' Conservação, vol. 13, no. 1, pp. 35-40. http://dx.doi.org/10.1016/j.ncon.2015.04.001.

GALETTI, M., CAMARGO, H., SIQUEIRA, T., KEUROGHLIAN, A., DONATTI, C.I., JORGE, M.L.S., PEDROSA, F., KANDA, C.Z. and RIBEIRO, M.C., 2015. Diet overlap and foraging activity between feral pigs and native peccaries in the Pantanal. PLoS One, vol. 10, no. 11, pp. e0141459. http://dx.doi.org/10.1371/journal. pone.0141459. PMid:26536608. 
GATTI, A., BIANCHI, R., ROSA, C.R.X. and MENDES, S.L., 2006. Diet of the crab-eating fox, Cerdocyon thous (Carnivora, Canidae) in Paulo Cesar Vinha State Park, Espírito Santo State, Brazil. Mammalia, vol. 70, no. 1-2, pp. 153-155. http://dx.doi. org/10.1515/MAMM.2006.021.

GONGORA, J., REYNA-HURTADO, R., BECK, H., TABER, A., ALTRICHTER, M. and KEUROGHLIAN, A., 2011. [viewed 06 June 2020]. Pecari tajacu [online]. The IUCN Red List of Threatened Species. Available from: https://www.iucnredlist.org/ species/41777/10562361

GROENENDIJK, J., DUPLAIX, N., MARMONTEL, M., VAN DAMME, P. and SCHENCK, C., 2015. [viewed 06 June 2020]. Pteronura brasiliensis [online]. The IUCN Red List of Threatened Species. Available from: https://www.iucnredlist.org/species/18711/21938411

GUIMARÃES, V.Y., CESCA, L.C.C., TROMBIN, D.F. and PINDER, L., 2015. New records of Speothos venaticus Lund, 1842 (Carnivora: Canidae) in the state of Pará, Brazil. Brazilian Journal of Biology = Revista Brasileira de Biologia, vol. 75, no. 3, suppl. 1, pp. 176-178. http://dx.doi.org/10.1590/1519-6984.02514BM. PMid:26691090.

GUTIÉRREZ, E.E. and MARINHO-FILHO, J., 2017. The mammalian faunas endemic to the Cerrado and the Caatinga. ZooKeys, vol. 644, no. 644, pp. 105-157. http://dx.doi.org/10.3897/ zookeys.644.10827. PMid:28144187.

HOFMAN, M.P., SIGNER, J., HAYWARD, M.W. and BALKENHOL, N., 2016. Spatial ecology of a herd of white-lipped peccaries (Tayassu pecari) in Belize using GPS telemetry: challenges and preliminary results. Therya, vol. 7, no. 1, pp. 21-38.

HRBEK, T., SILVA, V.M.F., DUTRA, N., GRAVENA, W., MARTIN, A.R. and FARIAS, I.P., 2014. A new species of river dolphin from Brazil or: how little do we know our biodiversity. PLoS One, vol. 9, no. 1, pp. e83623. http://dx.doi.org/10.1371/journal. pone.0083623. PMid:24465386.

INSTITUTO CHICO MENDES DE CONSERVAÇÃO DA BIODIVERSIDADE - ICMBIO, 2018. Livro vermelho da fauna brasileira ameaçada de extinção. Brasília, DF: ICMBio/MMA, 492 p.

INTERNATIONAL UNION FOR CONSERVATION OF NATURE - IUCN, 2020 [viewed 15 February 2021]. The IUCN Red List of Threatened Species. Version 2020-3 [online]. IUCN. Available from: https:// www.iucnredlist.org

JÁCOMO, A.T.A., 2004. Ecologia, manejo e conservação do queixada Tayassu pecari no Parque Nacional das Emas e em propriedades rurais de seu entorno. Brasília: Universidade de Brasília.

KEUROGHLIAN, A. and EATON, D.P., 2009. Removal of palm fruits and ecosystem engineering in palm stands by white-lipped peccaries (Tayassu pecari) and other frugivores in an isolated Atlantic Forest fragment. Biodiversity and Conservation, vol. 18, no. 7, pp. 1733-1750. http://dx.doi.org/10.1007/s10531008-9554-6.

KEUROGHLIAN, A., DESBIEZ, A., REYNA-HURTADO, R., ALTRICHTER, M., BECK, H., TABER, A. and FRAGOSO, J.M.V., 2013. [viewed 06 June 2020]. Tayassu pecari. [online]. The IUCN Red List of Threatened Species. Available from: https://www.iucnredlist. org/species/41778/44051115

KEUROGHLIAN, A., EATON, D.P. and LONGLAND, W.S., 2004. Area use by white-lipped and collared peccaries (Tayassu pecari and Tayassu tajacu) in a tropical forest fragment. Biological Conservation, vol. 120, no. 3, pp. 411-425. http://dx.doi. org/10.1016/j.biocon.2004.03.016.

KLINK, C.A. and MACHADO, R.B., 2005. Conservation of the Brazilian Cerrado. Conservation Biology, vol. 19, no. 3, pp. 707-713. http:// dx.doi.org/10.1111/j.1523-1739.2005.00702.x.

LATRUBESSE, E.M., AMSLER, M.L., MORAIS, R.P. and AQUINO, S., 2009. The geomorphologic response of a large pristine alluvial river to tremendous deforestation in the South American tropics: the case of the Araguaia River. Geomorphology, vol. 113, no. 3-4, pp. 239-252. http://dx.doi.org/10.1016/j.geomorph.2009.03.014.

LAURINDO, R.S., TOLEDO, F.R.N. and TEIXEIRA, E.M., 2019. Mammals of medium and large size in Cerrado remnants in southeastern Brazil. Neotropical Biology and Conservation, vol. 14, no. 2, pp. 195-206. http://dx.doi.org/10.3897/neotropical.14.e37653.

LEITE, R.J.V., LEMOS, J.L.F., SILVA, F.W.M.D., ALENCAR, I.R.C., BEZERRA, P.F. and CARREGARO, J.B., 2016. Composition of medium and large mammals in forest reserve in the Cerrado of Brazil Central. Revista Árvore, vol. 40, no. 5, pp. 825-832. http://dx.doi. org/10.1590/0100-67622016000500006.

LEWINSOHN, T. and PRADO, P.I., 2002. Biodiversidade brasileira: síntese do estado atual do conhecimento. São Paulo: Editora Contexto.

LIMA, M., PERES, C.A., ABRAHAMS, M.I., SILVA JUNIOR, C.A., DE MEDEIROS COSTA, G. and DOS SANTOS, R.C., 2019. The paradoxical situation of the white-lipped peccary (Tayassu pecari) in the state of Mato Grosso, Brazil. Perspectives In Ecology and Conservation, vol. 17, no. 1, pp. 36-39.

LIMA, P.C.A.D. and FRANCO, J.L.D.A., 2014. As RPPNs como estratégia para a conservação da biodiversidade: o caso da Chapada dos Veadeiros. Sociedade \& Natureza, vol. 26, no. 1, pp. 113-125. http://dx.doi.org/10.1590/1982-451320140108.

LUCHERINI, M., 2015. [viewed 07 September 2020]. Cerdocyon thous. [online]. The IUCN Red List of Threatened Species. Available from: https://www.iucnredlist.org/species/4248/81266293

MACENA, F., ASSAD, E. and EVANGELISTA, B.A., 2008. Caracterização climática do bioma Cerrado. In: S.M. SANO, S.P. ALMEIDA and J.F. RIBEIRO, eds. Cerrado: ecologia e flora. Brasília, DF: Embrapa Cerrados.

MAGURRAN, A.E., 2013. Measuring biological diversity. John Wiley \& Sons.

MARINHO-FILHO, J., RODRIGUES, F.H. and JUAREZ, K.M., 2002. The Cerrado mammals: diversity, ecology and natural history. In: P.S. Oliveira, and R.J. Marquis, eds. The Cerrados of Brazil. New York: Columbia University Press. pp. 266-284.http://dx.doi. org/10.7312/oliv12042-015

MARIONI, B., FARIAS, I., VERDADE, L.M., BASSETTI, L., COUTINHO, M.E., DE MENDONÇA, S.H., VIEIRA, T.Q., MAGNUSSON, W.E. and CAMPOS, Z., 2013. Avaliação do risco de extinção do jacaré-açu Melanosuchus niger (Spix, 1825) no Brasil. Corumbá: Embrapa Pantanal.

MARTINS, F.R. and SANTOS, F.D., 1999. Técnicas usuais de estimativa da biodiversidade. Revista Holos, vol. 1, no. 1, pp. 236-267.

MEDICI, E.P. and DESBIEZ, A.L.J., 2012. Population viability analysis: using a modeling tool to assess the viability of tapir populations in fragmented landscapes. Integrative Zoology, vol. 7, no. 4, pp. 356-372. http://dx.doi.org/10.1111/j.1749-4877.2012.00318.x. PMid:23253367.

MEDICI, E.P., 2010. Assessing the viability of lowland tapir populations in a fragmented landscape. Canterbury: Durrell Institute of Conservation and Ecology, University of Kent. PhD dissertation.

MEDICI, E.P., FLESHER, K., BEISIEGEL, B.M., KEUROGHLIAN, A., DESBIEZ, A.L.J., GATTI, A., MENDES-PONTES, A.R., CAMPOS, C.B., TOFOLI, C.F. and MORAES-JUNIOR, E.A., 2018. Tapirus terrestris (Linnaeus, 1758). In: ICMBIO, ed. Livro vermelho da fauna Brasileira ameaçada de extinçao. Brasília, DF: ICMBio. pp. 59-68.

MEDICI, E.P., FLESHER, K., DE MELLO BEISIEGEL, B., KEUROGHLIAN, A., DESBIEZ, A.L.J., GATTI, A., PONTES, A.R.M., DE CAMPOS, C.B., DE TÓFOLI, C.F., JÚNIOR, E.A.M. and DE AZEVEDO, F.C., 2012. Avaliação do risco de extinção da anta brasileira Tapirus 
terrestris Linnaeus, 1758, no Brasil. Biodiversidade Brasileira, no. 1, pp. 103-116.

MELO-SANTOS, G., RODRIGUES, A.L.F., TARDIN, R.H., MACIEL, I.S., MARMONTEL, M., SILVA, M.L. and MAY-COLLADO, L.J., 2019. The newly described Araguaian river dolphins, Inia araguaiaensis (Cetartiodactyla, Iniidae), produce a diverse repertoire of acoustic signals. Peerj - Aquatic Biology , vol. 7, pp. e6670. http:// dx.doi.org/10.7717/peerj.6670. PMid:31041149.

MELO-SANTOS, G., WALMSLEY, S.F., MARMONTEL, M., OLIVEIRADA-COSTA, M. and JANIK, V.M., 2020. Repeated downsweep vocalizations of the Araguaian river dolphin, Inia araguaiaensis. The Journal of the Acoustical Society of America, vol. 147, no. 2, pp. 748. http://dx.doi.org/10.1121/10.0000624. PMid:32113279.

MITTERMEIER, R.A. 1997. Megadiversity: earth's biologically wealthiest nations. Prado Norte: Agrupacion Sierra Madre.

MOORING, M.S., EPPERT, A.A. and BOTTS, R.T., 2020. Natural selection of melanism in Costa Rican Jaguar and Oncilla: a Test of Gloger's Rule and the Temporal Segregation Hypothesis. Tropical Conservation Science, vol. 13, pp. 1-15. http://dx.doi. org/10.1177/1940082920910364.

MOREIRA-JUNIOR, R.H.M., 2017. Avaliação da população de Botos-doAraguaia (Cetacea: Iniidae: Inia araguaiaensis Hrbek et al., 2014) no Baixo Rio Tocantins, Amazônia oriental. Belém: Universidade Federal do Pará, Instituto de Ciências Biológicas. Dissertação de mestrado.

MYERS, N., MITTERMEIER, R.A., MITTERMEIER, C.G., DA FONSECA, G.A. and KENT, J., 2000. Biodiversity hotspots for conservation priorities. Nature, vol. 403, no. 6772, pp. 853-858. http://dx.doi. org/10.1038/35002501. PMid:10706275.

NOONAN, P., PROUT, S. and HAYSSEN, V., 2017. Pteronura brasiliensis (Carnivora: mustelidae). Mammalian Species, vol. 49, no. 953, pp. 97-108. http://dx.doi.org/10.1093/mspecies/sex012.

OKSANEN, J., BLANCHET, F.G., KINDT, R., LEGENDRE, P., MINCHIN, P.R., O'HARA, R.B., SIMPSON, G.L., SOLYMOS, P., STEVENS, M.H.H., WAGNER, H. and OKSANEN, M.J., 2013. Community ecology package. Package 'vegan' [version 2(9)]. Vienna: R Foundation for Statistical Computing \& CRAN, $295 \mathrm{p}$.

OLIVEIRA, A.M., CARNICER, C., PAIVA, H.N., COSTA, R.P. and NETO, A.M., 2019. Medium and large mammals: indicators of buffer zones in reforestation. Scientific Electronic Archives, vol. 12, no. 5, pp. 79-85.

PAGLIA, A.P., DA FONSECA, G.A., RYLANDS, A.B., HERRMANN, G., AGUIAR, L.M., CHIARELLO, A.G. and MENDES, S.L., 2012. Annotated checklist of Brazilian mammals. Occasional Papers in Conservation Biology, vol. 6, no. 6, pp. 1-76.

PAOLINO, R.M., VERSIANI, N.F., PASQUALOTTO, N., RODRIGUES, T.F., KREPSCHI, V.G. and CHIARELLO, A.G., 2016. Buffer zone use by mammals in a Cerrado protected area. Biota Neotropica, vol. 16, no. 2. http://dx.doi.org/10.1590/1676-0611-BN-2014-0117.

PATTON, J.L., PARDIÑAS, U.F.J. and D'ELIA, G., 2015. Mammals of South America. Chicago: University of Chicago Press. Rodents, vol. 2.

PEREIRA, T.S.D.M., 2017. Distribuição e abundância de botos-doAraguaia (Inia araguaia-ensis) em trechos de rio fragmentados por eventos de seca. Belém: Universidade Federal do Pará, Instituto de Ciências Biológicas. Dissertação de mestrado.

PERES, C.A., 1996. Population status of white-lipped Tayassu pecari and collared peccaries T. tajacu in hunted and unhunted Amazonian forests. Biological Conservation, vol. 77, no. 2-3, pp. 115-123. http://dx.doi.org/10.1016/0006-3207(96)00010-9.

PINDER, L. and GROSSE, A.P., 1991. Blastocerus dichotomus. Mammalian Species, no. 380, pp. 1-4.
PIVARI, D., PACCA, H.M. and SEBRIAN, T., 2017. Occurrence of Botodo-Araguaia (Inia araguaiaensis) in a Region of the Araguaia River, Brazil, documented for an environmental impact study for a hydroelectric dam. Aquatic Mammals, vol. 43, no. 5, pp. 530-536. http://dx.doi.org/10.1578/AM.43.5.2017.530.

PORFIRIO, G., SARMENTO, P., XAVIER FILHO, N.L., CRUZ, J. and FONSECA, C., 2014. Medium to large size mammals of southern Serra do Amolar, Mato Grosso do Sul, Brazilian Pantanal. Check List, vol. 10, no. 3, pp. 473-482. http://dx.doi. org/10.15560/10.3.473.

PORTUGAL, M.P., MORATO, R.G., DE BARROS, K.M.P.M., RODRIGUES, F.H.G. and JACOBI, C.M., 2019. Priority areas for jaguar Panthera onca conservation in the Cerrado. Oryx, vol. 54, no. 6, pp. 854865. http://dx.doi.org/10.1017/S0030605318000972.

QUINTELA, F.M., DA ROSA, C.A. and FEIJÓ, A., 2020. Updated and annotated checklist of recent mammals from Brazil. Anais da Academia Brasileira de Ciências, vol. 92, suppl. 2, pp. 92. http:// dx.doi.org/10.1590/0001-3765202020191004. PMid:32813766.

R DEVELOPMENT CORE TEAM 2017. R: Language and environmentfor statistical computing [software]. Vienna: R Foundation for Statistical Computing.

RAMALHEIRA, C.S., BOZZETTI, B.F., CRUZ, A.D., PALMEIRIM, A.F., CABRAL, M.M. and ROSAS, F.C., 2015. First record of jaguar predation on giant otter (Pteronura brasiliensis). Animal Biology, vol. 65, no. 1, pp. 81-86. http://dx.doi.org/10.1163/1570756300002461.

RAMALHO, E.E. and MAGNUSSON, W.E., 2009. Uso do habitat por onça-pintada (Panthera onca) no entorno de lagos de várzea, Reserva de Desenvolvimento Sustentável Mamirauá, AM, Brasil. Scientific Magazine UAKARI, vol. 4, no. 2, pp. 33-39. http://dx.doi. org/10.31420/uakari.v4i2.41.

RHEINGANTZ, M.L. and TRINCA, C.S., 2015. [viewed 06 June 2020]. Lontra longicaudis. [online]. The IUCN Red List of Threatened Species. Available from: https://www.iucnredlist.org/ species/12304/21937379

RIBEIRO, J.F. and WALTER, B.M.T. 1998. Fitofisionomias do bioma Cerrado. In: S.M. SANO, S.P. ALMEIDA, eds. Cerrado: ambiente e flora. Planaltina: EMBRAPA-CPAC.

RIPPLE, W.J., ESTES, J.A., BESCHTA, R.L., WILMERS, C.C., RITCHIE, E.G., HEBBLEWHITE, M., BERGER, J., ELMHAGEN, B., LETNIC, M., NELSON, M.P. and SCHMITZ, O.J., 2014. Status and ecological effects of the world's largest carnivores. Science, vol. 343, no. 6167, pp. 1241484.

ROCHA, P.C. and COMUNELLO, E., 2009. Geomorfologia e áreas inundáveis na planície fluvial do alto Rio Paraná. In: Anais do 13ํㅗำósio Brasileiro de Geografia Física Aplicada, 06-10 Junho 2009, Viçosa, Viçosa: UFV, pp. 60-75.

RYLANDS, A.B., MITTERMEIER, R.A. and SILVA JUNIOR, J.S., 2012. Neotropical primates: taxonomy and recently described species and subspecies. International Zoo Yearbook, vol. 46, no. 1, pp. 11-24. http://dx.doi.org/10.1111/j.1748-1090.2011.00152.x.

SCARAMUZZA, C.D.M., MACHADO, R.B., RODRIGUES, S.T., NETO, M.R., PINAGÉ, E.R. and FILHO, J.D. 2008. Áreas prioritárias para conservação da biodiversidade em Goiás. In: L. FERREIRA JUNIOR, org. A encruzilhada socioambiental: Biodiversidade, economia e sustentabilidade no Cerrado. Goiânia: Editora UFG.

SCHMITZ, O.J., 2010. Resolving ecosystem complexity (MPB-47). Princeton: Princeton University Press.

SCHOLES, R.J. and BIGGS, R., 2005. A biodiversity intactness index. Nature, vol. 434, no. 7029, pp. 45-49. http://dx.doi.org/10.1038/ nature03289. PMid:15744293.

SICILIANO, S., VALIATI, V.H., EMIN-LIMA, R., COSTA, A.F., SARTOR, J., DORNELES, T., SILVA JUNIOR, J.S. and OLIVEIRA, L.R., 2016. 
New genetic data extend the range of river dolphins Inia in the Amazon Delta. Hydrobiologia, vol. 777, no. 1, pp. 255-269. http://dx.doi.org/10.1007/s10750-016-2794-7.

SOISALO, M.K. and CAVALCANTI, S.M., 2006. Estimating the density of a jaguar population in the Brazilian Pantanal using cameratraps and capture-recapture sampling in combination with GPS radio-telemetry. Biological Conservation, vol. 129, no. 4 pp. 487-496. http://dx.doi.org/10.1016/j.biocon.2005.11.023.

SRBEK-ARAUJO, A.C. and CHIARELLO, A.G., 2007. Armadilhas fotográficas na amostragem de mamíferos: considerações metodológias e comparação de equipamentos. Revista Brasileira de Zoologia, vol. 24, pp. 647-656. https://doi.org/10.1590/S010181752007000300016.

STRASSBURG, B.B., BROOKS, T., FELTRAN-BARBIERI, R., IRIBARREM, A., CROUZEILLES, R., LOYOLA, R., LATAWIEC, A. E., OLIVEIRA FILHO, F.J.B., SCARAMUZZA, C.A., SCARANO, F.R., SOARESFILHO, B. and BALMFORD, A., 2017. Moment of truth for the Cerrado hotspot. Nature Ecology \& Evolution, vol. 1, no. 4, pp. 1-3. https://doi.org/10.1038/s41559-017-0099.

TERBORGH, J., 2012. Enemies maintain hyperdiverse tropical forests. The American Naturalist, vol. 179, no. 3, pp. 303-314. http://dx.doi.org/10.1086/664183. PMid:22322219.

THORNTON, D.H., BRANCH, L.C. and SUNQUIST, M.E., 2011. The relative influence of habitat loss and fragmentation: do tropical mammals meet the temperate paradigm? Ecological Applications, vol. 21, no. 6, pp. 2324-2333. http://dx.doi.org/10.1890/102124.1. PMid:21939064.

TIEPOLO, L.M. and TOMAS, W.M., 2006. Ordem Artiodactyla. Mamíferos do Brasil, vol. 1, pp. 283-300.
TROLLE, M., BISSARO, M.C. and PRADO, H.M., 2007. Mammal survey at a ranch of the Brazilian Cerrado. Biodiversity and Conservation, vol. 16, no. 4, pp. 1205-1211. http://dx.doi. org/10.1007/s10531-006-9106-x.

TROLLE, M., NOSS, A.J., CORDEIRO, J.L.P. and OLIVEIRA, L.F.B., 2008. Brazilian tapir density in the Pantanal: a comparison of systematic camera-trapping and line-transect surveys. Biotropica, vol. 40, no. 2, pp. 211-217. http://dx.doi.org/10.1111/j.17447429.2007.00350.x

VARELA, D., FLESHER, K., CARTES, J.L., DE BUSTOS, S., CHALUKIAN, S., AYALA, G. and RICHARD-HANSEN, C., 2019. [viewed 06 September 2020]. Tapirus terrestris. [online]. The IUCN Red List of Threatened Species. Available from: https://www. iucnredlist.org/species/21474/45174127

WARD, J.V. and STANFORD, J.A., 1995. The serial discontinuity concept: extending the model to floodplain rivers. Regulated Rivers: Research and Management, vol. 10, no. 2-4, pp. 159-168. http://dx.doi.org/10.1002/rrr.3450100211.

WIEDMANN, S.M.P. 2001. Reserva particular do patrimônio naturalRPPN-na Lei $n^{0}$ 9.985/2000, que instituiu o sistema nacional de unidades de conservação-SNUC. Direito ambiental das áreas protegidas: o regime jurídico das unidades de conservação. Rio de Janeiro: Forense.

WILSON, D.E. and REEDER, D.M., 2005. Mammal species of the world: a taxonomic and geographic reference. Baltimore: Johns Hopkins University Press, vol. 1.

WORLD WIDE FUND FOR NATURE - WWF, 2015. Áreas prioritárias para conservação da biodiversidade no Cerrado e Pantanal. Brasília, DF: WWF-Brasil. 128 p. 


\section{Supplementary materials}

Supplementary material accompanies this paper.

Figure supplementary 1. Species recorded in the study area. A) Panthera onca; B) Puma concolor; C) Leopardus pardalis; D) Pteronura brasiliensis; E) Tapirus terrestres; F) Mazama americana; G) Mazama gouazoubira; H) Dicotyles tajacu; I) Cerdocyon thous; J) Myrmecophaga tridactyla; K) Tayassu pecari; L) Hydrochoerus hydrochaeris; M) Sapajus libidinosus; N) Alouatta guariba; O) Nasua.

Figure supplementary 2. Species recorded in the study area. A) Blastocerus dichotomus; B) Chrysocyon brachyurus; C) Didelphis albiventris; D) Dasypus novemcinctus; E) Procyon cancrivorus; F) Cuniculus paca; G) Priodontes maximus; H) Inia araguaiensis;

This material is available as part of the online article from http://www.scielo.br/bjb 